\title{
INTEGRASI PASAR SPASIAL TELUR AYAM RAS DI PROVINSI BENGKULU
}

\author{
SPATIAL MARKET INTEGRATION OF “TELUR AYAM RAS" IN \\ BENGKULU PROVINCE
}

\author{
Romauliyana Br Silalahi, M. Mustopa R, dan Redy Badrudin \\ Jurusan Sosial Ekonomi Pertanian Fakultas Pertanian Universitas Bengkulu \\ Email: abyaz_75@yahoo.co.id
}

\begin{abstract}
This research is the integration of the market of "Telur Ayam Ras" in the Bengkulu Province. The analized district that are the City of Bengkulu, South Bengkulu District, North Bengkulu District, and Rejang Lebong District. The purpose of this research was to analyze the price developments and analyze spatial market integration of "telur ayam ras". The data used is secondary data which is data price of "Telur Ayam Ras" in Bengkulu Province per month and taken during the past 10 years, starting in 2004 untill 2013. The analyze was performed by descriptive for price developments and to analyze spatial market integration is using Eviews 6 applications. Results of the research showed that the price development in the four districts fluctuates due to the influence of demand and supply, while integration of spatial market of eggs in the Bengkulu Province has already well integrated and there are two pairs of districts that interplay in the formation of prices, those are Bengkulu City with Rejang Lebong and South Bengkulu with North Bengkulu.
\end{abstract}

Keyword:Price Developments, Spatial Market Integration.

\section{PENDAHULUAN}

Produksi telur ayam ras mulai dari tahun 2010 ada sebesar 451,82 ton dan mengalami penurunan saat tahun 2011 menjadi sebesar 335,87 ton. Produksi telur ayam ras di Provinsi Bengkulu bersifat naik turun, jika di tahun 2011 turun, maka di tahun 2012 produksinya meningkat tajam hingga mencapai 575,71 ton per tahun. Tetapi tahun 2013 turun kembali menjadi 528,89 ton. Pada tahun 2014 produksinya sedikit beranjak menjadi 560,59 ton. Rata-rata pertumbuhan produksi telur di Provinsi Bengkulu sebesar 1,61\%. (BPS Prov. Bengkulu, 2015)

Sementara konsumsi telur ayam ras di Bengkulu berkaitan dengan permintaan. Berbeda dengan permintaan nasional yang tidak mengalami peningkatan secara signifikan, permintaan telur ayam ras di Provinsi Bengkulu cukup besar. Setiap tahunnya dari tahun 2011 terus mengalami kenaikan, dan yang paling signifikan terjadi lonjakan permintaan ditahun 2013. Di tahun 2012 permintaan hanya mencapai 2514,08 ton dan tahun 2013 menjadi 9596,59 ton. 
Kenaikan yang sangat pesat, tetapi tidak diiringi dengan jumlah produksi yang ada di Provinsi Bengkulu (Dinas Peternakan di Provinsi Bengkulu, 2015).

Selanjutnya Dinas Peternakan di Provinsi Bengkulu (2015) menunjukan bahwa rata-rata presentasi permintaan terhadap produksi mulai dari tahun 2011-2015 adalah 13,70\%. Ini menandakan bahwa produksi yang ada di Bengkulu hanya mampu mencukupi sebesar $13,70 \%$ dari seluruh total permintaan yang ada di Bengkulu. Hal ini berarti terdapat sekitar 86,3\% produksi yang berasal dari luar Bengkulu untuk memenuhi permintaan di Provinsi Bengkulu. Daerah atau wilayah yang memenuhi permintaan (supplier) telur ayam ras di Provinsi Bengkulu ini ada dua yaitu ada yang berasal dari Sumatera Utara dan Padang. Rata-rata pertumbuhannya adalah sebesar 7,62\%

Dari latar belakang di atas maka dapat diformulasikan rumusan masalah yang diangkat dalam penelitian ini adalah yang pertama bagaimanakah perkembangan harga telur ayam ras di Provinsi Bengkulu? dan yang kedua bagaimanakah integrasi spasial pasar telur ayam ras di Provinsi Bengkulu? Dengan demikian, tujuan penelitian ini adalah untuk menganalisis perkembangan harga telur ayam ras di Provinsi Bengkulu, Menganalisis integrasi spasial pasar telur ayam ras di Provinsi Bengkulu.

\section{METODE PENELITIAN}

Integrasi pasar komoditas hasil pertanian luas telah mulai menarik para peneliti, diantaranya Cahya Suryana, dkk (2014) dan Irawan, Andi dan Dewi Rosmayanti. (2007) tentang integrasi komoditas beras di Povinsi Bengkulu, serta Hariadi Subagja, Samet Hartono, Krisnha Agung Santosa, Jamhari (2011) tentang integrasi pasar daging ayam broiler di Provinsi Jawa Timur. Sandeep Saran and L.S. Gangwa (2008) tentang komoditas telur ayam di India terjadi integrasi pasar sebagai akibat peran dari the National Egg Coordination Committee (NECC), juga Sendhil R. , D. Babu , Ranjit Kumar and K. Srinivas. (2013) tentang kepastian penerapan hukum satu harga telur di India serta M.I. Omar et al (2014) tentang Sistem dan integrasi pasar telur ayam di Bangladesh.

Data yang digunakan dalam penelitian ini menggunakan data time series harga telur bulanan yang dikelola oleh Badan Pusat Statistik Provinsi Bengkulu di wilayah Kota Bengkulu, Bengkulu Selatan, Bengkulu Utara dan Rejang Lebong.

\section{Perkembangan Harga}

Perkembangan harga ini dapat dilihat dengan melakukan pendekatan secara grafis, dengan memasukkan rata-rata dari harga yang terjadi setiap tahun pada masing-masing kabupaten.

72 | Romauliyana Br Silalahi, M. Mustopa R, dan Redy Badrudin; ... 


\section{Pengujian Stasionaritas Peubah Atau Uji Akar Unit (Unit Root Test)/Kointegrasi}

Kointegrasi adalah hubungan yang terjadi antar variabel-variabel yang stasioner pada derajat yang sama. Kointegrasi ini merupakan alat analisis ekonometrika yang dapat menunjukkan keseimbangan jangka panjang antara variabel yang sangat erat berhubungan sebagai alat peramalan, maka dari itu stasioneritas data perlu dilakukan sebagai syarat penting dalam pengujian pendekatan kointegrasi (Maruddani, Tarno dan Anisah, 2008).

Stasioner dari data deret waktu dapat ditentukan dengan menggunakan Augmented Dicky-Fuller (ADF) test, dimana dapat dinyatakan dalam persamaan berikut (Irawan dan Rosmayanti, 2007):

$$
\Delta H B_{t}=\alpha_{0}+\alpha_{1} T+\delta H B_{t-1}+\sum_{i=1}^{k} \beta_{i} \Delta H B_{t-i}+\mu_{t}
$$

dimana: $\Delta \mathrm{HB}_{\mathrm{t}}$ merupakan operator perbedaan tingkat pertama, $H B_{\mathrm{t}-1}$ merupakan perubahan harga, $\mathrm{T}$ merupakan tren waktu (Januari 2004-Desember 2013), $\alpha_{0}, \alpha_{1}, \delta, \beta_{i}$ merupakan koefisien, $\mathrm{k}$ adalah jumlah lag, dan $\mu_{t}$ adalah merupakan galat persamaan.

Dalam uji ini digunakan aplikasi Eviews, jika nilai ADF $\leq$ nilai kritis maka data tersebut terdapat unit root atau dapat diartikan bahwa data tersebut tidak stasioner, dan sebaliknya jika nilai ADF > nilai kritis maka data tersebut tidak ada unit root atau diartikan sebagai data tersebut stasioner.

\section{Uji Vector Auto Regression (VAR)}

Penentuan panjang lag penting karena jika lagnya terlalu kecil, maka model yang digunakan kurang mampu menjelaskan hubungannya. Secara manual panjang lag dapat dicari dengan rumus sebagai berikut ini (Irawan dan Rosmayanti, 2007)

$$
H B_{t}=\mu+\Pi_{t} H B_{t-1}+\Pi_{k} H B_{t k-1}+\varepsilon_{t}
$$

dimana $\mathrm{HB}_{\mathrm{t}}$ merupakan vector harga telur rill (px1) pada waktu $t, \mu$ merupakan vector (px1) intercept, $\Pi_{1}$ dan $\Pi_{k}$ adalah Matriks parameter (pxp) i merupakan $1, \ldots, \mathrm{k} ., \mathrm{k}$ adalah Jumlah lag, serta $\varepsilon_{\mathrm{t}}$ merupakan vector galat berukuran (px1) dengan sifat mean sama dengan nol dan variance-covariance matrix, et merupakan $\mathrm{O}$.

Dalam penelitian ini, penentuan panjang lag ini dapat diketahui dengan mudah jika menggunakan aplikasi Eviews, dengan melihat nilai dari Akaike Information Criterion (AIC) (Gujarati, 2004 dalam Prakoso, 2009). 


\section{Uji Causality}

Menurut Prakoso (2009), secara manual pada pengujian pola causality granger dapat menggunakan uji F-test, dengan menetapkan hipotesa adalah Ho: $\mathrm{B}$ tidak mempengaruhi A dan Ha: B mempengaruhi A. Jika nilai F stat $>\mathrm{F}$ tabel pada level signifikan yang ditentukan, maka Ho ditolak dengan kata lain B mempengaruhi $\mathrm{A}$, dan jika $\mathrm{F}$ stat $\leq \mathrm{F}$ tabel pada level signifikan, maka tidak cukup bukti untuk menolak Ho, berarti B tidak mempengaruhi A. Alpha yang digunakan adalah alpha $5 \%$ dan $10 \%$. Jika probabilitas $\leq$ alpha, maka menolak Ho dengan kata lain variabel B mempengaruhi variabel A, dan begitu sebaliknya, jika probabilitas > alpha maka Ho diterima, yang berati variabel B tidak mempengaruhi variabel $\mathrm{A}$.

\section{HASIL DAN PEMBAHASAN}

\section{Perkembangan Harga Telur Ayam Ras}

Harga yang tercipta di setiap Kabupaten yang ada, sangat berfluktuasi, dan terlihat jelas sekali fluktuasi yang terjadi di Kabupaten Rejang Lebong adalah fluktuasi yang paling tertinggi. Hal ini terjadi karena Kabupaten Rejang Lebong adalah kabupaten yang letaknya lebih jauh dari pusat produksi telur ayam ras dibandingkan dengan kabupaten lain di Provinsi Bengkulu. Jika dibandingkan dengan Kota Bengkulu, harga yang tercipta cenderung lebih rendah karena Kota Bengkulu merupakan wilayah yang menjadi pusat perdagangan sehingga harga yang tercipta lebih rendah. Harga yang ada di Bengkulu Utara juga lebih stabil dikarenakan Bengkulu Utara merupakan wilayah yang lebih dekat dengan wilayah produksi telur ayam ras berlangsung. Fluktuasi di kedua wilayah ini tidak begitu signifikan dikarena ada beberapa alasan yaitu, kedua tempat ini adalah wilayah yang berdekatan dengan tempat produksi telur ayam ras berlangsung dan juga tempat dimana para distributor besar memasok telur ayam ras ditempat ini, sehingga stok telur ayam ras yang terus terjaga dan jumlah penawaran dan permintaan juga terus stabil sehingga menyebabkan harga tidak berfluktuasi seperti yang terjadi di Kabupaten Rejang Lebong.

74 | Romauliyana Br Silalahi, M. Mustopa R, dan Redy Badrudin; ... 


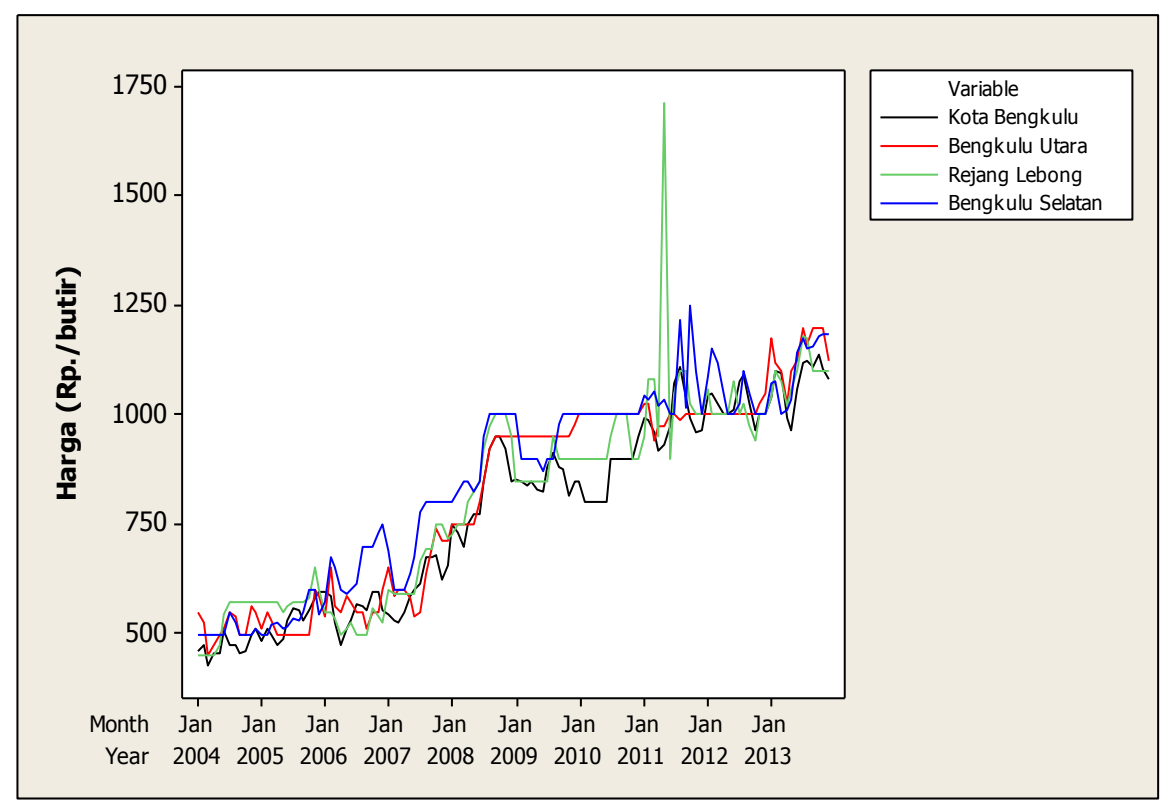

Gambar 1.

Fluktuasi Harga Telur Ayam di Empat Kabupaten di Provinsi Bengkulu.

Ada satu hal yang menarik dari grafik harga telur ayam ras yang tercipta di keempat Kabupaten tersebut, yaitu di sepanjang tahun 2011 terjadi peningkatan harga di setiap kabupaten. Ini mengindikasikan adanya keterkaitan harga yang tercipta disetiap wilayah tersebut. Jika dilihat dari data produksi BPS (2015), pada tahun 2011 produksi telur ayam ras di empat wilayah tersebut mengalami kemerosotan produksi, seperti wilayah Bengkulu Selatan di tahun 2010 produksinya adalah 48,40 ton dan turun menjadi 28,86 ton. Wilayah Rejang Lebong selama tahun 2009-2011 memang tidak melakukan produksi telur, sehingga data yang dihimpun oleh BPS tidak ada, dan untuk wilayah Bengkulu Utara pada tahun 2010 sebesar 209,38 ton, turun menjadi 132,65 ton. Wilayah Bengkulu Kota di tahun 2010 sebesar 151 ton menjadi 130,10 ton (tabel 6). Inilah yang menyebabkan mengapa pada tahun yang sama terjadi kenaikan harga yang cukup signifikan di keempat wilayah tersebut. Produksi pada tahun 2011 tersebut turun dikarenakan tahun tersebut sedang ada wabah penyakit (flu burung) yang menyerang unggas, Provinsi Bengkulu, Jambi dan Padang. 
Tabel 1. Produksi Telur Ayam Ras pada setiap Kabupaten di Provinsi Bengkulu (ton)

\begin{tabular}{|c|c|c|c|c|c|}
\hline No & Tahun & $\begin{array}{c}\text { Bengkulu } \\
\text { Selatan }\end{array}$ & $\begin{array}{l}\text { Rejang } \\
\text { Lebong }\end{array}$ & $\begin{array}{l}\text { Bengkulu } \\
\text { Utara }\end{array}$ & $\begin{array}{c}\text { Kota } \\
\text { Bengkulu }\end{array}$ \\
\hline 1 & 2004 & 38.903 & 37.538 & 105.105 & 58.013 \\
\hline 2 & 2005 & 500 & 5.871 & 16.762 & 9.0 \\
\hline 3 & 2006 & 3.39 & 21.88 & 120.35 & 63.47 \\
\hline 4 & 2007 & 3.39 & 21.680 & 120.35 & 63.510 \\
\hline 5 & 2008 & 2.50 & 22.75 & 126.30 & 64.19 \\
\hline 6 & 2009 & 31.29 & & 242.88 & 154.870 \\
\hline 7 & 2010 & 48.40 & & 209.38 & 151.0 \\
\hline 8 & 2011 & 28.86 & & 132.65 & 130.1 \\
\hline 9 & 2012 & 47.79 & 171.640 & 192.15 & 126.6 \\
\hline 10 & 2013 & 76.19 & 225.230 & 153.87 & 57.280 \\
\hline 11 & 2014 & 181.69 & 81.900 & 154.16 & 61.340 \\
\hline \multicolumn{2}{|c|}{ Jumlah } & 962.403 & 588.489 & $1,573.957$ & 939.373 \\
\hline \multicolumn{2}{|c|}{ Rata-rata } & 87.491 & 53.499 & 143.087 & 85.398 \\
\hline
\end{tabular}

Sumber : Data Sekunder diolah (2015).

\section{Integrasi Pasar}

Mengolah data sekunder dalam analisis integrasi diawali dengan menguji ke-stasioneran data tersebut. Uji yang digunakan adalah uji Unit Root dengan menggunakan aplikasi Eviews 6. Hasil estimasi ADF dengan menggunakan aplikasi Eviews 6 pada tingkat level (ordo level) terhadap data harga telur ayam ras diperoleh nilai hasil ADF < nilai kritis (critical value), sehingga itu menandakan bahwa data time series tersebut tidak stasioner sesuai tabel Mackinnon disetiap a. Tabel 2 menyajikan hasil estimasi stasioneritas data.

Estimasi diwilayah Rejang Lebong nilai ADF nya sebesar -1.3017 lebih kecil dibandingkan dengan nilai kritis sebesar -3.4870, demikian juga dengan wilayah lainnya, dan kesimpulannya bahwa dengan demikian tidak dapat menolak Ho, karena data tersebut tidak stasioner. Hasil uji ADF tingkat diferensi pertama (ordo 1) adalah nilai ADF > nilai kritisnya (critical value) pada masingmasing daerah, salah satu contohnya di daerah Rejang Lebong yaitu sebesar 13.3113 lebih besar dibandingkan nilai kritisnya yaitu sebesar -3.4870 , begitu juga dengan daerah lainnya seperti di daerah Bengkulu Selatan, Bengkulu Utara dan Kota Bengkulu. Dengan demikian hipotesis nol $(\mathrm{Ho})$ ditolak dan $\mathrm{Ha}$ diterima, yang menyatakan bahwa serial harga telur ayam ras dikabupaten yang ada di Provinsi Bengkulu berada pada satu akar unit (stasioner) pada tingkat first difference.

76 | Romauliyana Br Silalahi, M. Mustopa R, dan Redy Badrudin; ... 
Tabel 2. Uji Unit Root untuk Harga Ayam Ras di Provinsi Bengkulu tahun 2004-2013.

\begin{tabular}{|c|c|c|c|c|}
\hline Kabupaten & $\begin{array}{c}\text { Lag } \\
\text { Length }\end{array}$ & $\mathrm{ADF}$ & $\begin{array}{c}\text { Critical Value } \\
(1 \%)\end{array}$ & $\begin{array}{c}\text { Critical Value } \\
(5 \%)\end{array}$ \\
\hline RL (Curup) & 2 & -1.3017 & -3.4870 & -2.8863 \\
\hline BS (Manna) & 1 & -1.0456 & -3.4866 & -2.8861 \\
\hline BU (Arga Makmur) & 0 & -0.7177 & -3.4861 & -2.8859 \\
\hline KB (Bengkulu) & 2 & -0.9803 & -3.4870 & -2.8863 \\
\hline \multicolumn{5}{|c|}{ First difference of price series } \\
\hline Kabupaten & $\begin{array}{c}\text { Lag } \\
\text { Length }\end{array}$ & $\mathrm{ADF}$ & $\begin{array}{c}\text { Critical } \\
\text { Value }(1 \%)\end{array}$ & $\begin{array}{c}\text { Critical } \\
\text { Value }(5 \%)\end{array}$ \\
\hline RL (Curup) & 1 & -13.3113 & -3.4870 & -2.8863 \\
\hline BS (Manna) & 0 & -14.2274 & -3.4866 & -2.8861 \\
\hline BU (Arga Makmur) & 0 & -11.7145 & -3.4866 & -2.8861 \\
\hline KB (Bengkulu) & 1 & -9.8975 & -3.4870 & -2.8863 \\
\hline
\end{tabular}

Sumber : Data Sekunder diolah, 2016.

\section{Uji Vector Auto Regression (VAR)}

Berdasarkan hasil estimasi penentuan lag optimal, maka nilai kelambanan yang didapat jika ada perubahan yang terjadi disuatu wilayah maka tenggang waktu yang terjadi untuk di wilayah lain adalah max 2 bulan. Setelah selanjuntnya adalah uji kointegrasi Johansen Test (Trace). Menurut Gujarati (2003) dalam Widadie dan Sutanto (2012) hal ini dilakukan untuk mengestimasi dan menguji hubungan kointegrasi dalam.

\section{Tabel 3. Penentuan Panjang Lag Optimal}

\begin{tabular}{ccccccc}
\hline Lag & LogL & LR & FPE & AIC & SC & HQ \\
\hline 0 & -2789.408 & NA & $4.29 \mathrm{E}+15$ & 47.34589 & 47.43981 & 47.38403 \\
1 & -2465.676 & 620.0276 & $2.33 \mathrm{E}+13$ & 42.13011 & 42.59972 & 42.32078 \\
2 & -2446.365 & $35.67708^{*}$ & $2.20 \mathrm{e}+13^{*}$ & $42.07398^{*}$ & 42.91928 & 42.4172 \\
\hline
\end{tabular}

Sumber : Data Sekunder diolah, 2016

* indicates lag order selected by the criterion

LR: sequential modified LR test statistic (each test at $5 \%$ level)

FPE: Final prediction error

AIC: Akaike information criterion

SC: Schwarz information criterion

HQ: Hannan-Quinn information criterion 
Uji ini adalah uji yang digunakan untuk melihat apakah ada kointegrasi yang terjadi pada masing-masing data harga telur ayam ras di setiap kabupaten di Provinsi Bengkulu atau tidak.

Tabel 4. Uji Kointegrasi Johansen Test (Trace)

\begin{tabular}{|c|c|c|c|c|}
\hline \multicolumn{5}{|c|}{ Unrestricted Cointegration Rank Test (Trace) } \\
\hline Hypothesized & & Trace & 0.05 & $P r o h$ ** \\
\hline No. of $C E(s)$ & Eigenvalue & Statistic & Critical Value & Prod. \\
\hline None $^{*}$ & 0.187834 & 53.04212 & 40.17493 & 0.0016 \\
\hline At most 1 * & 0.117816 & 28.7002 & 24.27596 & 0.013 \\
\hline At most 2 * & 0.085064 & 14.03376 & 12.3209 & 0.0256 \\
\hline At most 3 & 0.030569 & 3.632352 & 4.129906 & 0.0672 \\
\hline
\end{tabular}

Trace test indicates 3 cointegrating eqn(s) at the 0.05 level

* denotes rejection of the hypothesis at the 0.05 level

Sumber: Data Sekunder Diolah, 2016.

Tabel 5. Uji Kointegrasi Johansen Test (Maximum Eigenvalue)

\begin{tabular}{|c|c|c|c|c|}
\hline \multicolumn{5}{|c|}{ Unrestricted Cointegration Rank Test (Maximum Eigenvalue) } \\
\hline Hypothesized & & Max-Eigen & 0.05 & $D_{r o h}^{* *}$ \\
\hline No. of $C E(s)$ & Eigenvalue & Statistic & Critical Value & Proo. \\
\hline None* & 0.187834 & 24.34192 & 24.15921 & 0.0472 \\
\hline At most 1 & 0.117816 & 14.66644 & 17.7973 & 0.1392 \\
\hline At most 2 & 0.085064 & 10.4014 & 11.2248 & 0.0696 \\
\hline At most 3 & 0.030569 & 3.632352 & 4.129906 & 0.0672 \\
\hline
\end{tabular}

Max-eigenvalue test indicates 1 cointegrating eqn(s) at the 0.05 level

* denotes rejection of the hypothesis at the 0.05 level

**MacKinnon-Haug-Michelis (1999) p-values

Sumber : Data Sekunder diolah, 2016.

Selanjutnya untuk melihat implikasi hubungan dari data harga telur ayam ras yang ada dilakukan juga uji- Maximum Eigen value. Menurut Widadie dan Sutanto (2012) dua test yang dilakukan untuk melihat vektor kointegrasi adalah dengan trace test dan Maximum Eigen value.

Hasil uji rangking Test Maximum Eigen value juga menolak hipotesis nol (Ho), atau menerima Ha yang menyatakan adanya kointegrasi. Hanya saja pada Test Maximum Eigen value ini hanya ada satu yang terindikasi kointegrasi dan selebihnya tidak. Dengan demikian, harga telur ayam ras yang ada pada masing-masing kabupaten yang ada di Provinsi Bengkulu memiliki kointegrasi.

78 | Romauliyana Br Silalahi, M. Mustopa R, dan Redy Badrudin; ... 
Test kointegrasi yang telah dilakukan menghasilkan bahwa adanya keterkaitan setiap pasar dalam perubahan harga yang terjadi (tabel 6). Berdasarkan hasil Estimasi VAR juga dapat dilihat nilai elastisitas yang terjadi pada masing-masing wilayah kabupaten yang saling terpengaruh. Berikut ini persamaannya:

Tabel 6. Uji Vector Autoregression pada Masing-masing Kabupaten.

\begin{tabular}{|c|c|c|c|c|}
\hline & $\begin{array}{l}\text { Bengkulu } \\
\text { Utara }\end{array}$ & Kota Bengkulu & $\begin{array}{l}\text { Rejang } \\
\text { Lebong }\end{array}$ & $\begin{array}{l}\text { Bengkulu } \\
\text { Selatan }\end{array}$ \\
\hline Bengkulu Utara (BU) & 0.729516 & 0.166963 & 0.618274 & 0.085157 \\
\hline \multirow[t]{2}{*}{$(-1)$} & $(0.10674)$ & $(0.10933)$ & $(0.25664)$ & $(0.14855)$ \\
\hline & {$[6.83437]^{*}$} & [ 1.52720$]$ & {$[2.40915]^{*}$} & [ 0.57326] \\
\hline Bengkulu Utara (BU) & 0.079378 & -0.110785 & -0.45073 & -0.05644 \\
\hline \multirow[t]{2}{*}{$(-2)$} & (0.10099) & $(0.10343)$ & $(0.24279)$ & $(0.14054)$ \\
\hline & {$[0.78604]$} & {$[-1.07111]$} & {$[-1.85644]$} & {$[-0.40158]$} \\
\hline Kota Bengkulu (KB) & 0.032451 & 1.034347 & 0.368579 & 0.425538 \\
\hline \multirow[t]{2}{*}{$(-1)$} & $(0.09871)$ & $(0.10110)$ & $(0.23732)$ & $(0.13737)$ \\
\hline & [0.32875] & {$[10.2311]^{*}$} & [ 1.55308$]$ & {$[3.09777]^{*}$} \\
\hline Kota Bengkulu (KB) & -0.060507 & -0.308937 & -0.02617 & -0.16405 \\
\hline \multirow[t]{2}{*}{ (2) } & $(0.10147)$ & (0.10393) & $(0.24397)$ & $(0.14122)$ \\
\hline & {$[-0.59627]$} & {$[-2.97251]^{*}$} & {$[-0.10728]$} & {$[-1.16166]$} \\
\hline \multirow{3}{*}{$\begin{array}{c}\text { Rejang Lebong (RL) } \\
(-1)\end{array}$} & 0.037676 & 0.048446 & 0.099394 & 0.000782 \\
\hline & $(0.03948)$ & $(0.04043)$ & $(0.09491)$ & $(0.05494)$ \\
\hline & {$[0.95436]$} & [ 1.19818$]$ & [ 1.04719$]$ & [ 0.01423] \\
\hline \multirow{3}{*}{$\begin{array}{l}\text { Rejang Lebong (RL) } \\
\qquad(-2)\end{array}$} & 0.039817 & 0.121439 & 0.264403 & -0.03467 \\
\hline & $(0.03969)$ & $(0.04066)$ & $(0.09544)$ & $(0.05524)$ \\
\hline & [ 1.00308$]$ & [ 2.98701]* & {$[2.77047]^{*}$} & {$[-0.62759]$} \\
\hline Bengkulu Selatan(BS) & 0.155902 & -0.005115 & 0.036913 & 0.504435 \\
\hline \multirow[t]{2}{*}{$(-1)$} & $(0.07182)$ & $(0.07356)$ & $(0.17268)$ & (0.09995) \\
\hline & [ 2.17071] $]^{*}$ & {$[-0.06953]$} & [ 0.21377] & {$[5.04685]^{*}$} \\
\hline Bengkulu Selatan (BS) & -0.010495 & 0.035047 & 0.057545 & 0.230410 \\
\hline \multirow[t]{2}{*}{$(-2)$} & $(0.07252)$ & $(0.07427)$ & $(0.17435)$ & $(0.10092)$ \\
\hline & {$[-0.14473]$} & [ 0.47187] & [ 0.33005] & {$[2.28310]^{*}$} \\
\hline \multirow[t]{3}{*}{ C } & -3.155058 & 8.034406 & 39.01466 & 31.15331 \\
\hline & $(13.0282)$ & (13.3435) & $(31.3230)$ & (18.1308) \\
\hline & {$[-0.24217]$} & {$[0.60212]$} & [ 1.24556$]$ & [ 1.71826$]$ \\
\hline R-squared & 0.978492 & 0.974816 & 0.874180 & 0.955580 \\
\hline
\end{tabular}

Keterangan : ${ }^{*}=$ menunjukan signifikan pada taraf $5 \%$ ( $t$ statistik $\left.>2\right)$.

[ ] $=t$-statistik ()$=$ Standart Error

Sumber: Data Sekunder diolah, 2016. 


\section{Persamaan model 1:}

$$
\begin{aligned}
\mathrm{BU}= & \mathrm{BU}(-1)+\mathrm{BS}(-1) \\
\mathrm{BU}= & 0,729516 \mathrm{BU}(-1)+0,155902 \mathrm{BS}(-1) \\
& (0,10674) \quad(0.07182)
\end{aligned}
$$

Harga telur ayam ras di Bengkulu Utara berdasarkan uji VAR menyatakan bahwa harga tersebut dipengaruhi oleh harga sebelumnya BU (-1) dan juga dipengaruhi oleh harga yang tercipta di Bengkulu Selatan (-1), jadi harga yang terbentuk di Bengkulu Utara adalah perpaduan dari harga di Bengkulu Utara sendiri dan juga wilayah Bengkulu Selatan dengan elastisitas pada Bengkulu Utara sebesar 0,729516 dan pada Bengkulu Selatan 0,155902. Elastisitas ini mengartikan bahwa jika pada bulan lalu harga di Bengkulu Utara naik sebesar 1 persen, maka di bulan berikutnya akan naik sebesar 0,729516 persen, begitu juga untuk harga yang ada di Bengkulu Selatan, jika pada bulan lalu naik 1 persen, maka bulan ini akan naik sebesar 0,155902. Jika dilihat dari kenyataan yang ada di lapangan, jarak wilayah Bengkulu Utara dan Bengkulu Selatan cukup jauh, bagaimana mungkin Bengkulu Selatan mampu mempengaruhi Bengkulu Utara dalam pembentukan harga. Ditelusuri lebih lanjut, bahwa hipotesis yang timbul adalah harga yang ada di Bengkulu Selatan tersebut adalah transmisi harga yang ada di Kota Bengkulu, karena hasil estimasi VAR pada tabel 10 menunjukan pembentukan harga telur ayam ras untuk wilayah Bengkulu Selatan ternyata di pengaruhi oleh wilayah Kota Bengkulu, dan hal itu terjadi pada lag pertama (1).

\section{Persamaan model 2:}

$$
\begin{aligned}
& \mathrm{KB}=\mathrm{KB}_{\mathrm{t}-1}+\mathrm{KB}_{\mathrm{t}-2}+\mathrm{RL}_{\mathrm{t}-1} \\
& \mathrm{~KB}=1.034347 \mathrm{~KB}(-1)-0.308937 \mathrm{~KB}(-2)+0.121439 \mathrm{RL}(-2) \\
& (0.10110) \quad(0.10393)
\end{aligned}
$$
(0.10110)
(0.10393)
(0.04066)

Elastisitas yang tercipta di Kota Bengkulu menunjukan bahwa jika pada bulan lalu Kota Bengkulu mengalami kenaikan harga 1 persen, maka bulan berikutnya akan mengalami kenaikan sebesar 1,034347 persen dan jika pada bulan kedua mengalami penurunan 1 persen, maka dua bulan kemudian akan mengalami penurunan di dua bulan berikutnya sebesar $-0,308937$ persen. Jika di Rejang Lebong di dua bulan lalu mengalami penurunan 1 persen, maka di Kota Bengkulu akan mengalami penurunan juga sebesar 0,121439 persen. Koefisien lag pertama (-1) pada harga beras hasil estimasi uji VAR menghasilkan bahwa harga telur yang terbentuk di Kota Bengkulu adalah harga yang berasa dari harga sebelumnya KB (-1) dan KB (-2) dan selain itu harga tersebut juga terbentuk dari harga yang ada di Rejang Lebong (-2). Hal ini dikarenakan Kota Bengkulu merupakan wilayah yang memiliki populasi yang lebih banyak dibandingkan dengan wilayah lain, sehingga Kota Bengkulu menjadi pusat konsumsi telur di Provinsi Bengkulu. 


\section{Persamaan model 3:}

$$
\begin{aligned}
\mathrm{RL} & =\mathrm{BU}(-1)+\mathrm{RL}(-2) \\
\mathrm{RL} & =0.618274 \mathrm{BU}(-1)+0.264403 \mathrm{RL}(-2) \\
(0.25664) & (0.09544)
\end{aligned}
$$

Bengkulu Utara elastisitas harga yang ada 0,618274 pada lag pertama (-1) mengartikan bahwa jika pada bulan lalu mengalami kenaikan 1 persen, maka bulan berikutnya juga akan mengalami kenaikan sebesar 0,618274 persen, dan jika dua bulan lalu Rejang Lebong juga mangalami kenaikan harga, maka dua bulan kemudian juga akan mengalami kenaikan sebesar 0,264403 persen. Melihat hasil tersebut mengartikan bahwa Bengkulu Utara mampu mempengaruhi harga telur ayam ras yang ada di Rejang Lebong, ini berarti Bengkulu Utara memiliki kekuatan dalam penentuan harga yang tercipta di Rejang Lebong. Harga telur ayam ras tersebut juga tercipta dikarenakan dipengaruhi oleh harga yang telah lalu di wilayah Rejang Lebong (-2).

\section{Persamaan model 4:}

$$
\begin{aligned}
\mathrm{BS}= & \mathrm{KB}(-1)+\mathrm{BS}(-1)+\mathrm{BS}(-2) \\
\mathrm{BS}= & 0.425538 \mathrm{~KB}(-1)+0.504435 \mathrm{BS}(-1)+0.230410 \mathrm{BS}(-2) \\
& (0.13737)
\end{aligned}
$$

Hasil uji VAR menunjukan elastisitas harga telur ayam ras di Bengkulu Selatan lebih dipengaruhi oleh harga yang kemarin dan juga harga di Kota Bengkulu. Jika ada kenaikan 1 persen pada bulan lalu dan dua bulan lalu maka, dari nilai elastisitasnya maka bulan berikutnya dan dua bulan mendatang harga tersebut juga akan meningkat sebesar 0.504435 persen di bulan depan dan dua bulan kemudian sebesar 0.230410 persen. Bengkulu Selatan dengan kata lain lebih menguasai pembentukan harga dibanding wilayah lain, tetapi Kota Bengkulu juga mempengaruhi pembentukan harga yang tercipta disini. Jika ada kenaikan harga sebesar 1 persen di Kota Bengkulu pada bulan lalu, maka akan naik juga di bulan kemudian di Bengkulu Selatan.

Ada yang menarik dari hasil estimasi VAR pada tabel 6, jika digambarkan dalam sebuah alur maka setiap wilayah sebenarnya terintegrasi satu dengan yang lain, sehingga membentuk suatu perpaduan pasar yang saling berkaitan, berikut adalah alur perpaduan pasar berdasarkan uji VAR. 


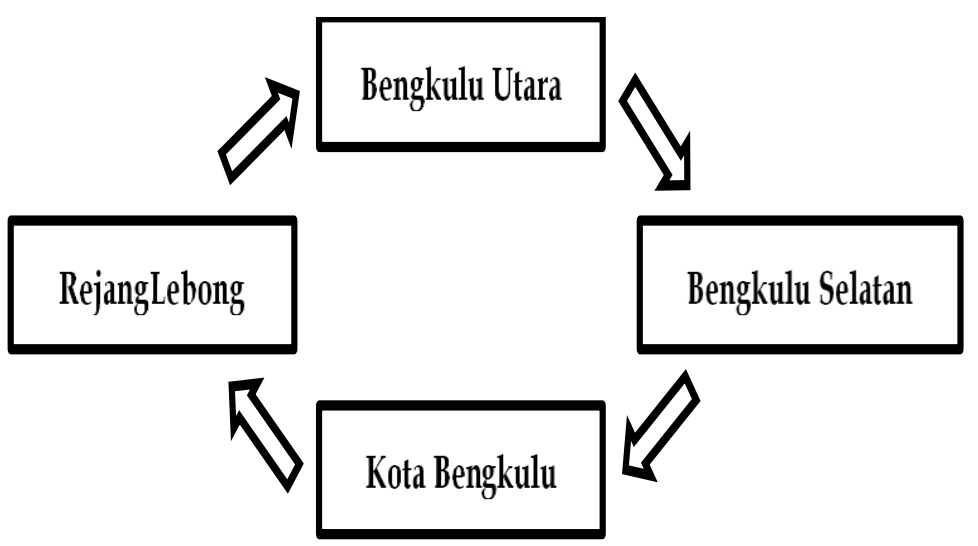

Gambar 2.

Skema Uji VAR Pengaruh Wilayah dalam Pembentukan Harga

\section{Causality Test}

Uji Causality ini bertujuan untuk melihat manakah pasar kabupaten yang saling mempengaruhi dan melihat kabupaten mana yang berhasil menjadi pasar pemimpin di Provinsi Bengkulu ini. Hasil uji Causality pada harga pasar telur ayam ras di Provinsi Bengkulu adalah sebagai berikut:

Tabel 4. Uji Causality Harga Telur Ayam Ras di Provinsi Bengkulu

\begin{tabular}{|c|c|c|c|c|c|}
\hline & \multicolumn{4}{|c|}{$\mathrm{Ke}$} \\
\hline & & KB & $\mathrm{BU}$ & BS & RL \\
\hline \multirow{4}{*}{$\overrightarrow{\tilde{D}}$} & Kota Bengkulu (KB) & & $1.84963 \mathrm{~ns}$ & $9.37476^{*}$ & $9.89774^{*}$ \\
\hline & Bengkulu Utara (BU) & $3.9165^{* *}$ & & $2.3801^{* * *}$ & $10.6422 \mathrm{~ns}$ \\
\hline & Bengkulu Selatan (BS) & $2.05044 \mathrm{~ns}$ & $5.36337^{*}$ & & $6.92274^{*}$ \\
\hline & Rejang Lebong (RL) & $8.08643^{* * *}$ & $2.67310^{* * *}$ & $1.55618 \mathrm{~ns}$ & \\
\hline
\end{tabular}

Sumber: Data Sekunder diolah, 2016.

Ket $:{ }^{*}=99 \%{ }^{* *}=95 \%{ }^{* * *}=90 \%$ dan ns $=$ Tidak Berpengaruh Nyata

\section{Kausalitas Kota Bengkulu}

Hasil uji Causality dengan kelambanan dua (lag-2) menunjukan bahwa harga telur ayam ras yang ada pada Kota Bengkulu hanya dipengaruhi oleh Bengkulu Selatan (BS) dan juga Rejang Lebong (RL) pada taraf kepercayaan 99\%. Ini menyatakan bahwa jika harga yang ada di Bengkulu Selatan atau Rejang Lebong mengalami kenaikan, maka harga yang ada di Kota Bengkulu juga akan naik. Tetapi harga telur ayam ras yang ada di Kota Bengkulu tidak dipengaruhi oleh harga yang ada di Bengkulu Utara karena berdasarkan nilai probabilitasnya lebih besar dibandingkan dengan nilai alpha yang digunakan. Kenaikan harga

82 | Romauliyana Br Silalahi, M. Mustopa R, dan Redy Badrudin; ... 
yang terjadi di kedua wilayah tersebut akan direspon oleh Kota Bengkulu dalam jangka waktu dua bulan, maka itu harga telur ayam ras di Bengkulu Selatan dan Rejang Lebong akan naik dalam waktu dua bulan berdasarkan hasil lag yang sudah didapat.

\section{Kausalitas Bengkulu Selatan}

Harga telur ayam ras yang ada Kabupaten Bengkulu Selatan dipengaruhi oleh harga telur ayam ras yang ada di Bengkulu Utara dan Rejang Lebong yaitu pada taraf kepercayaan 99\% pada alpha 0,01, ini mengindikasikan jika terjadi kenaikan harga di wilayah Bengkulu Utara dengan wilayah Rejang Lebong maka akan berpengaruh terhadap Bengkulu Selatan, tetapi untuk harga yang ada di Kota Bengkulu tidak dipengaruhi oleh harga yang ada di Bengkulu Selatan. Kenaikan ini juga dapat diterima oleh wilayah lain dalam waktu 2 bulan berdasarkan nilai lag yang didapat. Hal ini bisa saja terjadi dikarenakan faktor jumlah produksi telur ayam ras di Bengkulu Utara dan Rejang Lebong lebih banyak dibandingkan produksi yang ada di Bengkulu Selatan, sehingga kedua wilayah tersebut lebih berpengaruh dalam pembentukan harga telur ayam ras yang ada di Bengkulu Selatan.

\section{Kausalitas Rejang Lebong}

Rejang Lebong memiliki dua wilayah yang terintegrasi yaitu Kota Bengkulu dengan Bengkulu Utara dengan taraf kepercayaan 90\% pada alpha 0,1. Sedangkan dengan Bengkulu Selatan tidak mempengaruhi harga yang tercipta di Rejang Lebong. Rejang Lebong dengan Kota Bengkulu saling mempengaruhi karena terjadi timbal-balik dalam penentuan harga di wilayah masing-masing, karena jumlah produksi telur ayam ras yang ada di Kabupaten Bengkulu Utara dan Kota Bengkulu karena produksi di kedua wilayah lebih banyak dibandingkan produksi yang ada di Rejang Lebong. Rata-rata produksi di wilayah Bengkulu Utara dan Kota Bengkulu pada tahun 2004-2014 adalah 151,928 ton dan 90,124 ton sedangkan produksi yang ada di Rejang Lebong adalah sebesar 56,619 ton. Dengan demikian inilah yang menyebabkan Bengkulu Utara dan Kota Bengkulu sebagai penentu harga yang ada di Rejang Lebong.

\section{Kausalitas Bengkulu Utara}

Hasil estimasi kausalitas untuk wilayah Kabupaten Bengkulu Utara dipengaruhi oleh Kota Bengkulu dan Bengkulu Selatan. Pada Kota Bengkulu taraf kepercayaan terjadinya kausalitas adalah sebesar 95\% dengan alpha 0,05 dan untuk wilayah Bengkulu Selatan taraf kepercayaannya 90\% dengan alpha 0,1 . Arti dari estimasi tersebut adalah menghasilkan bahwa jika terjadi kenaikan harga di Bengkulu Utara itu merupakan pengaruh yang terjadi dari Kota Bengkulu dan juga Bengkulu Selatan. 
Adapun gambar alur tersebut dijelaskan pada Gambar 3. Gambar 3 dengan jelas memperlihatkan adanya alur integrasi pasar spasial telur ayam ras yang terjadi di Provinsi Bengkulu walaupun dengan taraf kepercayaan atau alpha yang berbeda-beda. Dengan demikian pasar telur ayam ras yang ada di Provinsi Bengkulu sudah terintegrasi dengan baik, dan tidak terjadi segmentasi. Hal ini dikarenakan adanya informasi pasar yang baik yang masih terjadi di provinsi sehingga saat ada kenaikan harga di suatu wilayah langsung direspon dengan wilayah lainnya. Berdasarkan Gambar 3 tidak terlihat adanya leader atau pasar pemimpin dalam penentuan harga telur ayam ras yang tercipta di keempat kabupaten tersebut, karena setiap harga yang ada di wilayah tersebut dipengaruhi oleh wilayah-wilayah lainnya.

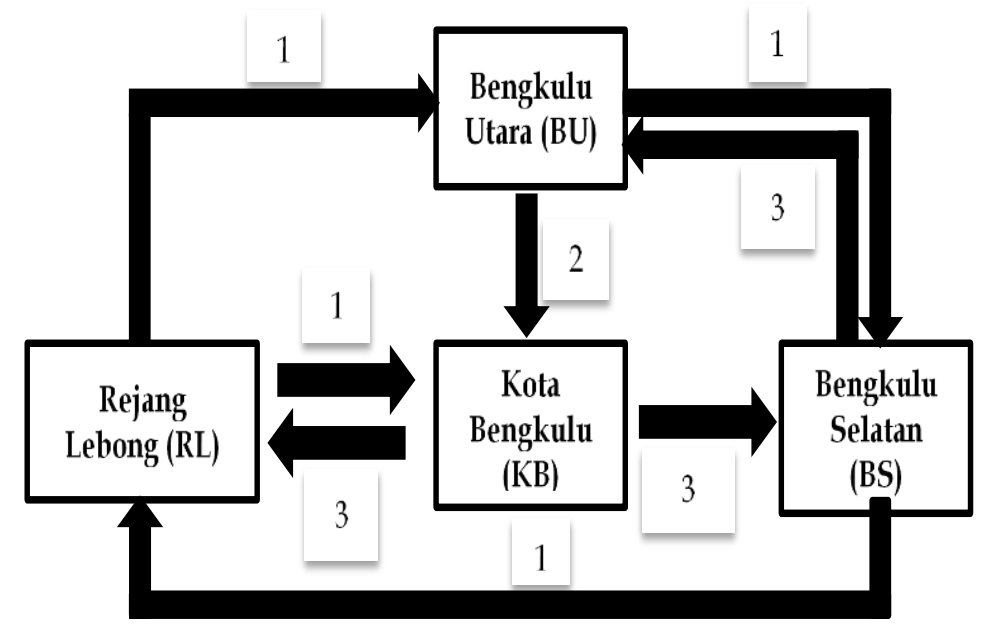

Keterangan: $1=a: 0,1 \quad \begin{gathered}2=a: 0,05 \\ \mathbf{2}=\text { Dipengaruhi }\end{gathered}$

\section{Gambar 3.}

Denah Alur Integrasi Spasial Pasar Telur Ayam Ras di Provinsi Bengkulu.

Penelitian ini sejalan dengan tiga peneliti integrasi pasar spasial. Peneliti pertama, (Sandeep Saran* and L.S. Gangwa. 2008) melakukan riset pada harga telur secara time series dari para pedagang telur "major wholesale egg markets" seperti Nammakal (Tamil Nadu), Calcutta, Chennai, Bangalore, Delhi and Hyderabad for the period 1982 to 2000. Studi ini berhasil menunjukkan bahwa enam negara bagian memiliki "cointegrated" nampaknya dikarenakan kinerja dari fungsi intelegensi pasar oleh komisi koordinasi telur nasiaonal atau "the National Egg Coordination Committee" (NECC) yang menolong men-transmisikan sinyal harga ke seluruh negara bagian melalui media tertulis setiap hari atau "on day-to-day basis". Semakin tinggi tingkat "cointegration" diantara berbagai pasar mengindikasikan pasar yang kompetitif dan efisien.

84 | Romauliyana Br Silalahi, M. Mustopa R, dan Redy Badrudin; ... 
Peneliti kedua, Sendhil R. et al (2013), integrasi pasar Sendhil R. et al (2013) keragaan integrasi pasar spasial di India, dengan menggunkan metode yang sama dengan penelitian ini, yaitu unit root dan penerapan the Augmented Dickey Fuller test statistic, cointegration mengindikasikan terdapat "a strong spatial integration between regional egg prices" pada jangka panjang. meskipun demikian hukum satu harga telur belum terjadi di India ataupun di seluruh negara bagiannya. Demikian juga peneliti ketiga dari Bangladesh, M.I. Omar et al (2014) dalam penelitian "Marketing System and Market Integration of Different Egg Markets" salah satu hasilnya adalah terterjadinya intergasi pasar telur secara spasial di Bangladesh. Kasus integrasi pasar spasial telur ayam di berbagai negara dan negara bagian ini dapat dijadikan pelajaran untuk Indonesia, khususnya Bengkulu untuk dapat lebih mengintegrasikannya dengan melakukan dan atau meningkatkan diseminasi harga baik secara berkala atau bahkan lebih baik lagi penyampaian informasi itu "real time" atau "day to day price information".

\section{SIMPULAN DAN SARAN}

\section{Simpulan}

1. Perkembangan harga telur ayam ras di Provinsi Bengkulu pada masingmasing kabupaten mengalami kenaikan dan berfluktuasi selama 10 tahun terakhir, dimulai dari tahun 2004-2013. Harga telur ayam ras yang mengalami fluktuasi tertinggi terjadi pada tahun 2011 dan yang terendah tahun 2007.

2. Pasar telur ayam ras di Provinsi Bengkulu terintegrasi sebagian. Integrasi Kota Bengkulu dan Kabupaten Rejang Lebong, serta Kabupaten Bengkulu Selatan dengan Bengkulu Utara.

\section{Saran}

Adanya integrasi pasar spasial telur ayam ras yang terjadi di Provinsi Bengkulu akan sangat membantu produsen dan konsumen, karena dengan demikian harga yang terjadi di kabupaten lain dapat segera diketahui oleh kabupaten lainnya karena sinyal harga yang tercipta ditransmisikan dengan baik, serta untuk mempertahankan stabilitas harga telur ayam ras yang sudah tercapai perlu adanya program pemerintah tingkat nasional, seperti India memiliki komisi koordinasi telur nasiaonal (NECC) sebagai intelegesi pasar. Pengembangan usaha peternakan yang ada pada empat kabupaten yang terintegrasi agar dapat meningkatkan pendapatan para peternak telur ayam ras berupa peminjaman modal. Dengan demikian diharapkan Provinsi Bengkulu sudah dapat memenuhi permintaan telur ayam ras sendiri. Diperlukan penelitian lanjutan "grass root" dari pedagang wholeseller atau "grosir" sampai 
ke peternak baik itu tentang struktur, perilaku dan kineja pasar yang menghasilkan pasar yang kompetitif dan efisien.

\section{DAFTAR PUSTAKA}

Badan Pusat Statistis Provinsi Bengkulu, 2015. Bengkulu dalam Angka 2014. Bengkulu

Dinas Peternakan dan Kesehatan Hewan Provinsi Bengkulu. 2015. Produksi dan Konsumsi Ternak Provinsi Bengkulu. Dinas Peternakan Provinsi Bengkulu, Bengkulu.

Irawan, Andi dan Dewi Rosmayanti. 2007. Analisis Integrasi Pasar Beras di Bengkulu. Universitas Bengkulu, Bengkulu. Jurnal Agro Ekonomi 25 (1): 37-54.

Maruddani, Di Asih I., Tarno dan Anisah, Rokhma Al. 2008. Uji Sasioneritas Data Inflasi dengan Phillips-Peron Test. Media Statistik 1 (1) : 27-34.

M.I. Omar M.A. Islam M.S. Hoq M.T. Islam. 2014. Marketing System and Market Integration of Different Egg Markets in Bangladesh Developing Country Studies www.iiste.org ISSN 2224-607X (Paper) ISSN 2225-0565 (Online) Vol.4, No.3, 201491 http://iiste.org/Journals/index.php/ DCS/ article/view/10883diunduh 23 April 2016 puku 16.12

Prakoso, Andrian Tony. 2009. Analisis Hubungan Kausalitas Antara FDI, Ekspor Dan Pertumbuhan Ekonomi. Universitas Indonesia, Depok.

Widadie, Fanny dan A. Sutanto. 2012. Model Ekonomi Perberasan: Analisis Integrasi Pasar Dan Simulasi Kebijakan Harga. SEPA 8 (2):1 - 17

Cahya Suryana, Putri Suci Asriani, dan Redy Badrudin. 2014. Perilaku harga dan integrasi pasar horizontal beras di Povinsi Bengkulu. Jurnal AGRISEP 14 No. 2 September 2014 Hal: 131 - 146. ISSN: 1412-8837

Hariadi Subagja , Samet Hartono , Krisnha g Santosa, Jamhari. 2011. Analisis integrasi pasar harga ayam broiler di Provinsi Jawa Timur. Jurnal AGRISEP 10 (1): 1 - 9.Maret 2011

Sandeep Saran* and L.S. Gangwa. 2008. Analysis of Spatial Cointegration amongst Major Wholesale Egg Markets in India . Central Avian Research Institute, Izatnagar-243 122, Bareilly, Uttar Pradesh Agricultural Economics Research Review Vol. 21 July-December 2008 pp 259-263 http://ageconsearch.tind.io// bitstream/47680/2/12-SSaran.pdf diunduh 23 April 2016 puku 16.00

Sendhil R. , D. Babu , Ranjit Kumar and K. Srinivas. 2013. How far do egg markets in India conform to the law of one price? African Journal of Agricultural Research.8(48): pp. 6093-6100

86 | Romauliyana Br Silalahi, M. Mustopa R, dan Redy Badrudin; ... 